Vol. 4, No. 1, 2018

\author{
Volodymyr Malashchenko ${ }^{1}$, Oleh Strilets ${ }^{2}$, Volodymyr Strilets ${ }^{3}$ \\ ${ }^{1}$ Department of Technical Mechanics and Machines Dynamics, Lviv Polytechnic National University, \\ 12, S. Bandera Str., Lviv, Ukraine, E-mail: volod.malash@gmail.com \\ ${ }^{2}$ Department of Analythical Mechanics, Engineering Graphics and Mechanical Engineering, National University \\ of Water and Environmental Engineering, 11, Soborna Str., Rivne, Ukraine, E-mail: o.r.strilets@ nuwm.edu.ua \\ ${ }^{3}$ Department of Analythical Mechanics, Engineering Graphics and Mechanical Engineering, National University \\ of Water and Environmental Engineering, 11, Soborna Str., Rivne, Ukraine, E-mail: v.m.strilets@nuwm.edu.ua
}

\title{
THEORETICAL FOUNDATIONS FOR THE DEVELOPMENT OF EXPERIMENTAL EQUIPMENT FOR DETERMINING THE LOAD CAPACITY OF SPEED CHANGE DEVICES
}

Received: March 21, 2018 / Revised: June 05, 2018 / Accepted: June 26, 2018

() Malashchenko V., Strilets O., Strilets V., 2018

\begin{abstract}
The article gives the theoretical base for construction of equipment for experimental research of static, kinematic and dynamic characteristics of devices for speed change by epicyclic gear trains with closed circuit hydrosystems through the ring gear during the transmission by them of the periodic, shock long-term or short-term loads or their executive mechanism stoppage due to overload. This equipment can be successfully used for experimental study of devices for speed change by epicyclic gear trains with closed circuit hydrosystems through the carriers or sun gears.
\end{abstract}

Keywords: speed change device, experimental equipment, epicyclic gear train, stand, kinematics, statics, dynamics.

\section{Introduction}

In order to change the speed in modern machinery, methods and devices are widely used in the form of stepped, stepless or combined gear boxes [1]-[4]. Existing speed management methods and devices have many shortcomings. The main disadvantages of stepped speed control are the complexity of the design of these devices, their large material capacity, and large dynamic loads that arise when shifting from one speed to another. In stepless speed control there is a great deal of wear of the drive elements due to the use of friction brakes and locking friction clutches. As a result, the durability and reliability of drive elements and machines in general decreases. Therefore, there is a problem of creating new speed change management methods and devices that eliminate these shortcomings. The substantiation of the theoretical foundations of the process of speed changes control by epicyclic gear trains [5] and the development on the level of invention of cargo stop gears $[6,7]$ in the form of closed circuit hydrosystems and their application in differential gear transmissions, led to the creation of new devices for stepless speed changes control [8]. Developed devices are the matter of special interest because they eliminate these shortcomings.

\section{Problem Statement}

Such devices require conducting kinematic and power theoretical and experimental studies, knowledge of energy efficiency estimated by the efficiency coefficient, the possibility of self-braking and optimization of parameters during design. The fulfilment of these tasks for new speed control devices using epicyclic gear trains and a closed circuit hydrosystems is an urgent task for engineering.

\section{Review of Modern Information Sources on the Subject of the Paper}

Devices for speed changes control by epicyclic gear trains with closed circuit hydrosystems were first described in [9]. Theoretical scientific data about them was reported at scientific and technical conferences, 
symposia [10-15], and others, where questions aroused about their kinematic possibilities, which were further considered in works [16-24], performance efficiency coefficients [25]-[27]. Moreover, work [28] is devoted to 3D modeling of such devices. Obtained analytical solutions of actual problems are theoretical basis and require further experimental research and confirmation of the obtained results in real practical situations for different kinematic and power modes of operation of various executive mechanisms.

\section{Objectives and Problems of Research}

The purpose of the work is to obtain the scientifically grounded principles of the development of equipment for the experimental study of speed change devices through epicyclic gear trains with closed circuit hydrosystems during the transmission of periodic, shock long-term and short-term loads and their significant overload, up to the stop of their executive mechanism.

\section{Main Material Presentation}

For the experimental studies of kinematic, static and dynamic characteristics of speed change devices, a stand was developed [29]-[31] containing an epicyclic gear train and a closed circuit hydrosystem.

One of the schemes of epicyclic gear train with the device for speed changes control through the ring gear, shown in Fig. 1, consists of a sun gear 1, planets 2, ring gear 3 and a carrier 4 located in the housing 5. On the housing 5 there is a closed circuit hydrosystem 6 connected with the ring gear 3 by a gear transmission 7 .

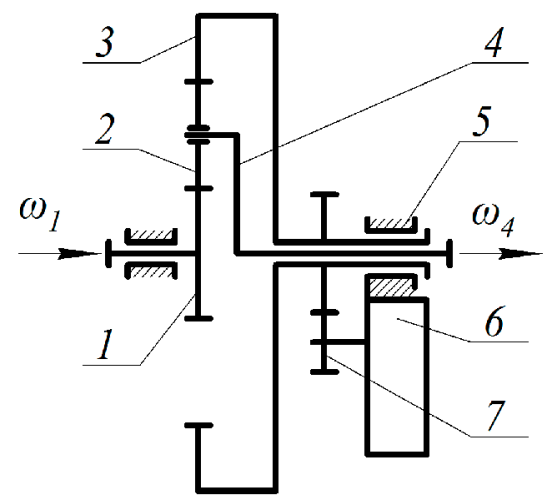

$a$

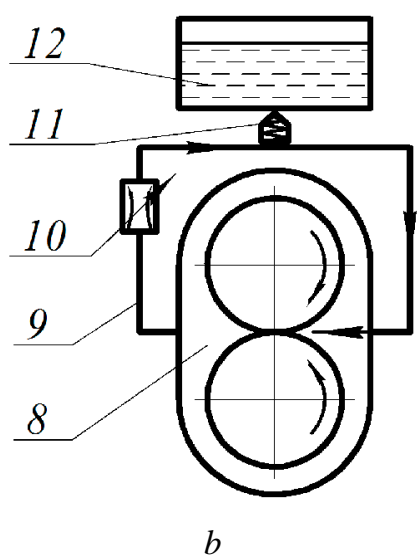

Fig. 1. Principle schemes: a - epicyclic gear train with a closed circuit hydrosystem; $b$ - a closed circuit hydrosystem

The closed circuit hydrosystem 6 consists of a hydraulic pump 8, pipelines 9 , a regulating valve 10 , a return valve 11 and a tank for liquid 12 .

For drives containing devices for changing speeds through epicyclic gear trains with closed circuit hydrosystems, there are four distinct cases of load variation in the form of a torque on the executive mechanism, the graphs of which are shown in Fig. 2: $a$ - the load varies periodically over a long period of time; $b$ - the magnitude of the shock load after a sharp increase remains unchanged for a long time; $c$ - the magnitude of the shock load after a sharp increase is maintained over a short period of time; $d$ - the executive mechanism instantly stops due to a significant overload.

For the experimental study of speed changes devices through epicyclic gear trains with closed circuit hydrosystems, a stand designed to realize the following four characteristic cases of load variation in the form of a torque on the executive mechanism and to perform kinematic, static and dynamic studies.

The stand shown in Fig. 3, consists of: frame 1; engine 2; the test device 3 for speed change by epicyclic gear train with a closed circuit hydrosystem (the inner part is not shown); coupling 4, brake pulley 5; a lever 6 with a brake shoe 7 fixed hingingly with one end on the support 8 , and the second end through the adjusting screw 9 interacts with the profile cam 10 mounted on the second engine 11 . The legs 12 serve to position the frame horizontally. 


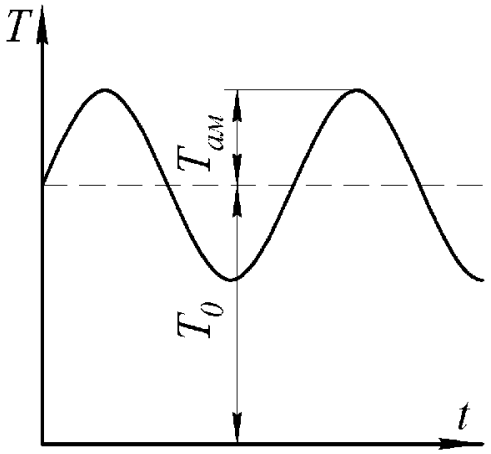

$a$

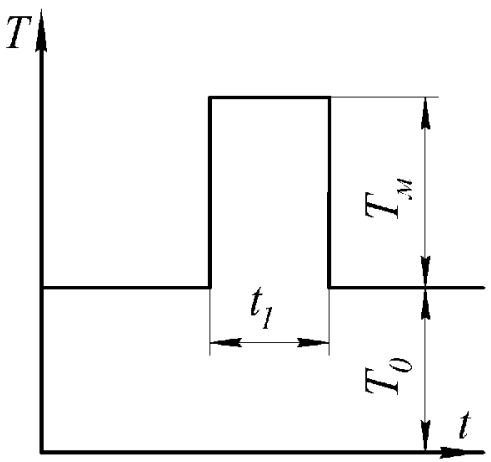

$c$

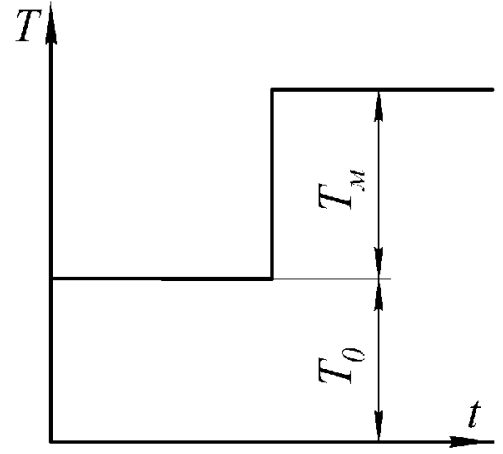

$b$

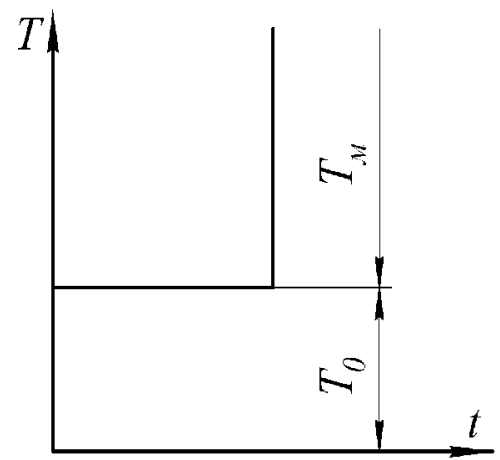

$d$

Fig. 2. Graphs of load variation - torque: a - the load varies periodically over a long period of time; $b$ - the magnitude of the shock load after a sharp increase remains unchanged for a long time; $c$ - the magnitude of the shock load after a sharp increase is maintained over a short period of time; $d$-the executive mechanism instantly stops due to a significant overload

The algorithm for studying the speed change device is as follows. The test speed change device 3 is being set on frame 1 and connected with engine 2 by coupling 4 . The adjusting screw 9 sets the necessary movement of the lever 6 relative to the proximity of the profile cams 10 .

The initial position of the lever is created by a compression spring so that there is a slight clearance between the brake pulley and the brake shoe for idling. After turning on the engine, the torque through the coupling is transmitted to the test speed change device and through it to the brake pulley. Next, a second motor with a profile cam is inserted, which moves the lever from the brake shaft through the adjusting screw, pushing it to the brake pulley, creating a load within the height of the profile of the profile cam, and then returning to its original position under the action of the compression spring force. Load cycle depends on the profile cam, and the load frequency from the rotational speed of the second engine shaft and the number of profiles on the initial disk of the profile cam.

Stand for speed change devices study with load mode as in Fig. 2, b, shown in Fig. 4, is similar to the previous one and consists of the frame 1 , engine 2 , test device 3 , coupling 4 , the brake pulley 5 , the lever 6 with the brake shoe 7, fixed hinged one end on the support 8 , and the second end rests on the compression spring 9. A guide device 10 set over the second end of the lever, which includes vertical guides 11 connected by a crossbar 12 to a mobile carriage 13 with a falling load 14 . On the crossbar, there is a lever hook 15 for fixation of carriage with falling load at height and its release in the time required.

Research of power parameters of speed change devices is as follows. Engine and test device with the brake pulley set on the frame and interconnect with the coupling. The initial position of the lever is created by a compression spring so that there is a small clearance between the brake pulley and the brake shoe for idling. On the giude device we lift the moving carriage, hang it on the lever hook and set the falling load. After turning on the engine, the torque through the coupling is transmitted to the test speed change device and through it to the brake pulley. Further, a mobile carriage with a falling load is released and load falls on the lever with the brake shoe, pressing it against the brake pulley, creating a shock durable load. 
Stand to speed change devices study with loading mode as in Fig. 2, $c$, shown in Fig. 5, similar to the previous, but from the side of the frame 1 on the vertical guides 11 of the guide device 10 there are compression springs 16 which, in the compressed state, are fixed by the clips 17 .

Research of speed change devices is being performed the same way as described above for the stand shown in Fig. 4. The research differs only by the fact that when a load falls on a lever with a brake shoe, pressing it to the brake pulley, creating a shock load, at that time a moving carriage with a falling load interacts with the clips and releases compression springs that lift the moving carriage with the falling load in the reverse direction, releasing the lever from the long-lasting load.

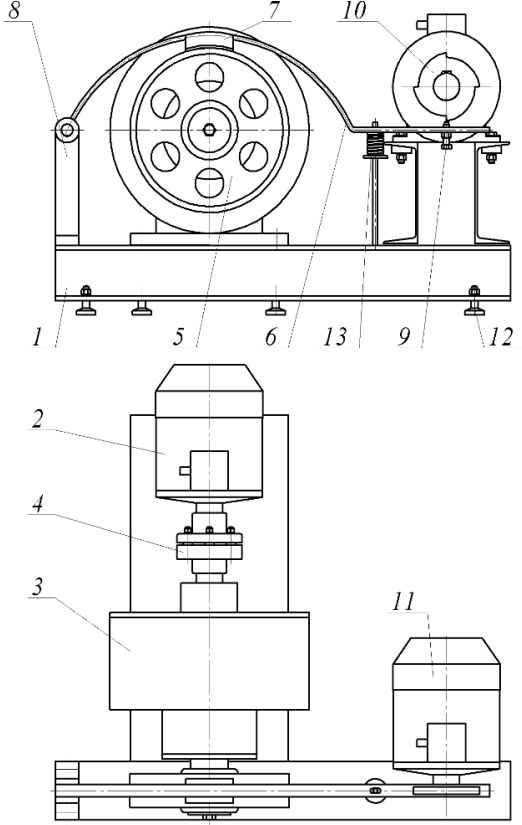

Fig. 3. Scheme of the stand for research of speed change devices when periodic load changes for a long time

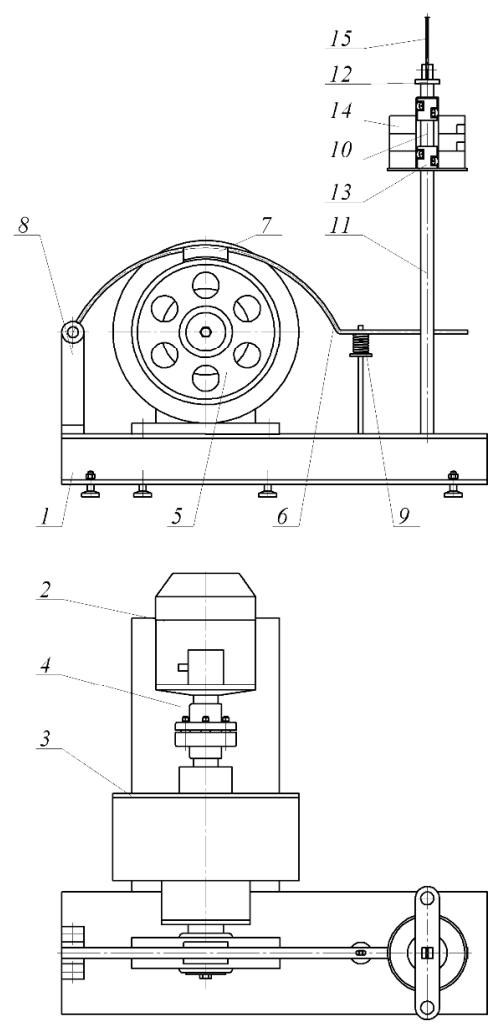

Fig. 4. Scheme of the stand for research of speed change devices when the load, after a sharp increase remains unchanged for a long time

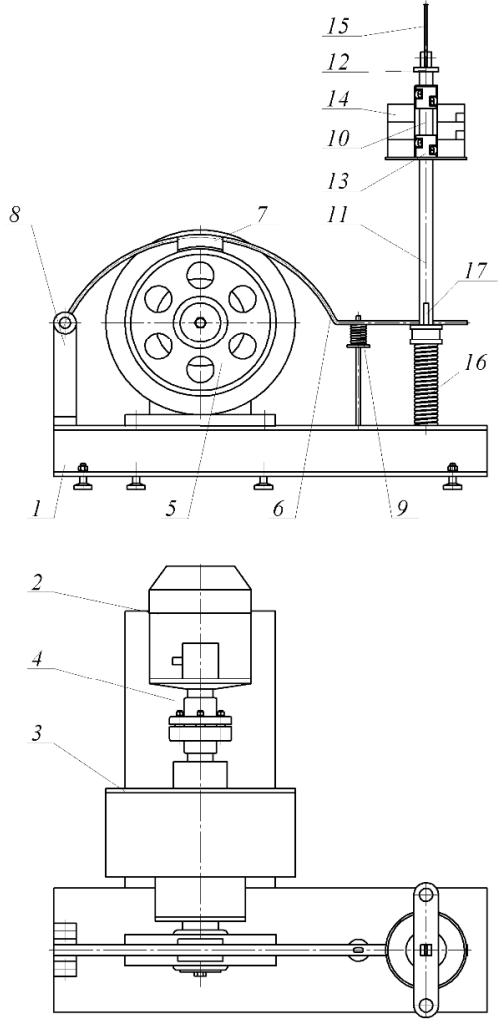

Fig. 5. Scheme of the stand for research of speed change devices when the load, after a sharp increase remains unchanged for a short time

Measurement of the magnitude of the kinematic, static and dynamic characteristics of the investigated speed change device with closed circuit hydrosystems is carried out by known methods and devices - standard tachometers, resistor sensors, tensor stations, and the like, described in [32].

\section{Conclusions}

The developed equipment for the experimental study of kinematic and power characteristics of speed change devices using Epicyclic gear trains with closed circuit hydrosystems through the ring gear ensures the verification of the obtained theoretical results and allows for their refinement during the transmission of their periodically variable, shock long and short-term load and significant overload, up to stop of the executive mechanism. The work is a solid ground for conducting experimental experiments of speed change devices using gear epicyclic gear trains with closed circuit hydrosystems through a carrier or sun gear for drives of various branches of mechanical engineering.

\section{References}

[1] V. O. Malashchenko, V. M. Strilets, and O. R. Strilets, "Ohlyad ta analiz sposobiv i prystroyiv skhodynkovoho keruvannya zminamy shvydkosti v tekhnitsi" ["Review and analysis of the methods and devices for 
stepped speed changes control in engineering"], Visnyk Natsionalnoho universytetu vodnoho hospodarstva ta pryrodokorystuvannia [Bulletin of the National university of water and environmental engineering], vol. 2 (70), pp. 245-255, 2015. [in Ukrainian].

[2] O. R. Strilets, "Ohlyad ta analiz sposobiv i prystroyiv bezskhodynkovoho i kombinovanogo keruvannya zminamy shvydkosti v tekhnitsi" ["Review and analysis of the methods and devices for continuously variable and combined speed changes control in engineering"], Visnyk Natsionalnoho universytetu vodnoho hospodarstva ta pryrodokorystuvannia [Bulletin of the National university of water and environmental engineering], vol. 2 (70), pp. 354-363, 2015. [in Ukrainian].

[3] V. O. Malashchenko, V. M. Strilets, and O. R. Strilets, "Fundamentals of Creation of New Devices for Speed Change Management", Ukrainian Journal of Mechanical Engineering and Materials Science. vol. 1, no. 2, pp. 11-20, 2015.

[4] V. O. Malashchenko, O. R. Strilets, and V. M. Strilets, "Klasyfikatsiya sposobiv i prystroyiv keruvannya protsesom zminy shvydkosti v tekhnitsi" ["Classification of methods and devices for speed changes control in engineering"], Pidyomno-transportna tekhnika [Hoisting and transport equipment], vol. 1, pp. 70-78, 2015. [in Ukrainian].

[5] O. R. Strilets, "Obgruntuvannya mozhlyvosti keruvannya zminamy shvydkosti za dopomohoyu dyferentsialnykh peredach" ["Justification of the possibility of speed changes control by epicyclic gear train"], Visnyk Inzhenernoyi akademiyi Ukrayiny [Bulletin of the Engineering Academy of Ukraine], vol. 2, pp. 177-181, 2015. [in Ukrainian].

[6] N. M. Kudenko, and V. M. Strilets, "Ostanov dlya gruza peremeshchayemogo mekhanizmom podyema" [Stop gear for cargo transported by lifting mechanism], RU Patent 2211796, September 10, 2003. [in Russian].

[7] N. M. Kudenko, and V. M. Strilets, "Vantazhoupornyy zupynnyk" [Cargo stop gear], UA Patent 41191, July 15,2003 . [in Ukrainian].

[8] O. R. Strilets, "Zubchastyy dyferentsial z prystroyem dlya keruvannya zminamy shvydkosti" [Epicyclic gear train for speed changes control], UA Patent 25335, August 19, 2008. [in Ukrainian].

[9] O. R. Strilets, V. M. Strilets, and I. T. Shynkarenko, "Keruvannya zminamy shvydkosti za dopomohoyu zubchastoyi dyferentsialnoyi peredachi" ["Speed changes control by epicyclic gear train"], Mashynoznavstvo [Mechanical Engineering], vol. 6 (120), pp. 38-41, 2007. [in Ukrainian].

[10] O. R. Strilets, "Ohlyad i analiz sposobiv keruvannya zminamy shvydkosti u tekhnitsi" ["Review and analysis of ways to control speed changes in engineering"], 12 Mizhnarodnyy sympozium ukrayinskykh inzhenerivmekhanikiv u Lvovi: tezy [Proceedings of 12th International Symposium of Ukrainian Mechanical Engineers in Lviv], pp. 152-153, 2015. [in Ukrainian].

[11] O. R. Strilets, "Sposoby keruvannya zminamy shvydkosti u tekhnitsi" ["Ways of speed changes control in engineering”], Zbirnyk tez 8 Mizhnarodnoyi naukovo-praktychnoyi konferentsiyi „Intehrovani intelektual'ni robototekhnichni kompleksy" IIRTK-2015 [Proceedings of 8th International scientific and practical conference "Integrated intellectual robotic complexes" IIRTC-2015], pp. 230-232, 2015. [in Ukrainian].

[12] O. R. Strilets, "Kinematychni mozhlyvosti zubchastykh dyferentsial $\square$ nykh peredach z zamknutoyu hidrosystemoyu" ["Kinematic possibilities of gear epicyclic gear trains with closed circuit hydrosystem"], Materialy Mizhnarodnoyi naukovo-tekhnichnoyi konferentsiyi molodykh uchenykh $i$ studentiv "Aktual $\square$ ni zadachi suchasnykh tekhnolohiy" [Proceedings of the International Scientific and Technical Conference of Young Scientists and Students "Current Problems of Modern Technologies"], chapter I, pp. 234-235, 2015. [in Ukrainian].

[13] V. O. Malashchenko, O. R. Strilets, V. M. Strilets, "Zalezhnist koefitsiyenta korysnoyi diyi zubchastoyi dyferentsialnoyi peredachi vid peredatochnoho chysla i shvydkosti keruvannya" ["Dependence of the coefficient of efficiency of the epicyclic gear train from the gear ratio and the control speed"], Materialy konferentsiyi prysvyachenoyi 110-richchyu S.M. Kozhevnykova [Proceedings of the conference devoted to the 110th anniversary of S. M. Kozhevnikov], Dnipro, pp. 145-148, 2017. [in Ukrainian].

[14] O. R. Strilets, "KKD zubchastoyi dyferentsial $\square$ noyi peredachi u prystroyi dlya keruvannya zminamy shvydkosti cherez sonyachne zubchaste koleso" ["Efficiency of the epicyclic gear train in the device for speed changes control through the sun gear"], Materialy konferentsiyi Odes $\square$ koyi derzhavnoyi akademiyi budivnytstva ta arkhitektury [Proceedings of the conference of the Odessa State Academy of Civil Engineering and Architecture], Odesa, pp. 145-149, 2017. [in Ukrainian].

[15] O. R. Strilets, "Vyznachennya KKD bahatoskhodynkovykh zubchastykh dyferentsial $\square$ nykh peredach u prystroyi zminy shvydkosti cherez epitsyk1 ["Definition of efficiency of multi-stage epicyclic gear trains in the device for speed changing through the ring gear"], 20 naukova konferentsiya TNTU imeni Ivana Pulyuya: materialy [Proceedings of XX conference in Ternopil Ivan Puluj National Technical University], Ternopil, pp. 51-52, 2017. [in Ukrainian].

[16] O. R. Strilets, "Keruvannya zminamy shvydkosti za dopomohoyu dyferentsial $\square$ noyi peredachi cherez epitsykl" ["Speed changes control by epicyclic gear train through ring gear"], Visnyk Ternopilskoho natsionalnoho 
tekhnichnoho universytetu [Scientific Journal of the Ternopil National Tachnical University], vol. 4(80), pp. 129-135, 2015. [in Ukrainian].

[17] O. R. Strilets, "Keruvannya protsesom zminy shvydkosti za dopomohoyu dyferentsial'noyi peredachi cherez sonyachne zubchaste koleso" ["Speed change process management by epicyclic gear train through sun gear"], Visnyk Khmelnytskoho natsionalnoho universytetu [Herald of Khmelnytskyi National University], vol. 5 (229), pp. 68-72, 2015. [in Ukrainian].

[18] O. R. Strilets, "Keruvannya protsesom zminy shvydkosti za dopomohoyu dyferentsial $\square$ noyi peredachi cherez vodylo" ["Speed change process management by epicyclic gear train through carrier"], Visnyk Kremenchutskoho natsionalnoho universytetu imeni Mykhaila Ostrohradskoho [Transactions of Kremenchuk Mykhailo Ostrohradskyi National University], vol. 6 (95), pp. 87-93, 2015. [in Ukrainian].

[19] V. O. Malashchenko, O. R. Strilets, and V. M. Strilets, "Method and device for speed change by the epicyclic gear train with stepped-planet gear set", Research Works of Air Force Institute of Technology, vol. 38, pp. 13-19, 2016.

[20] V. O. Malashchenko, O. R. Strilets, and V. M. Strilets, "Novyy sposob besstupenchatogo izmeneniya skorosti pri pomoshchi zubchatykh differentsial'nykh peredach s zamknutoy gidrosistemoy" ["A new way of infinitely variable speed variation by epicyclic gear train with a closed circuit hydrosystem"], Privody i komponenty mashin [Drives and Components of Machines], vol. 4-5, pp. 7-10, 2016. [in Russian].

[21] V. O. Malashchenko, O. R. Strilets, and V. M. Strilets, "Keruvannya zminamy shvydkosti za dopomohoyu bahatoshodynkovoi dyferentsialnoyi peredachi cherez sonyachne zubchaste koleso" ["Speed changes management by multistage epicyclic gear train through sun gear”], Vestnik Nacional $\square$ nogo tehničeskogo universiteta "HPI". Problemy mehaničeskogo privoda [Bulletin of the National Technical University "Kharkiv Polytechnic Institute". Problems of mechanical drive], vol. 23 (1195), pp. 87-92, 2016. [in Ukrainian].

[22] V. O. Malashchenko, O. R. Strilets, and V. M. Strilets, "Keruvannya shvydkistyu rukhu mashyn bahatostupenevoyu zubchastoyu peredacheyu cherez epitsykl" ["Machines speed of motion management by multistage epicyclic gear train through ring gear"], Visnyk Natsionalnoho universytetu "Lvivska politekhnika". Dynamika, mitsnist ta proektuvannya mashyn i pryladiv. [Bulletin of Lviv Polytechnic National University. Dynamics, strength and design of machines and devices], vol. 838, pp. 57-63, 2016. [in Ukrainian].

[23] V. O. Malashchenko, O. R. Strilets, and V. M. Strilets, "Novyy pryvod z dyferentsialom i zamknutoyu hidrosystemoyu dlya keruvannya shvydkistyu mashyny" ["New drive with differential and closed circuit hydrosystem for controlling the machine speed"], Vibratsii $v$ tekhnitsi ta tekhnolohiiakh [Vibrations in technique and technologies], vol. 3 (83), pp. 109-116, 2016. [in Ukrainian].

[24] A. V. Vavilov, V. O. Malashchenko, O. R. Strilets, and V. M. Strilets, "Sovershenstvovaniye transmissiy dorozhnykh mashin dlya povysheniya ikh konkurento-sposobnosti i obespecheniya importozameshcheniya" ["Improving the transmission of road cars to enhance their competitive abilities and ensure import substitution"], Avtomobilnyye dorogi i mosty [Highways and Bridges], vol. 2 (18), pp. 102-108, 2016. [in Russian].

[25] V. O. Malashchenko, O. R. Strilets, and V. M. Strilets, "Justification of efficiency of epicycle gear train in device for speed changes management", Ukrainian Journal of Mechanical Engineering and Materials Science, vol. 3, no. 1, pp. 89-95, 2017.

[26] O. R. Strilets, "The efficiency of the epicyclic gear train to devices for controlling the speed change through a sun gear", Pratsi Odeskoho politekhnichnoho universytetu [Odeskyi Politechnichnyi Universytet. Pratsi], vol. 2 (52), pp. 29-38, 2017.

[27] V. O. Malashchenko, O. R. Strilets, and V. M. Strilets, "Determining performance efficiency of the differential in a device for speed change through epicycle", Eastern-European Journal of Enterprise Technologies. vol. 6/7 (90), pp. 51-57, 2017.

[28] O. R. Strilets, "Kompyuterne modelyuvannya dyferentsialnykh peredach z prystroyem dlya keruvannya shvydkistyu" ["Computer modeling of epicyclic gear train with device to control speed"], Mashynoznavstvo [Mechanical Engineering], vol. 4 (128), pp. 35-39, 2009. [in Ukrainian].

[29] O. R. Strilets, V. O. Malashchenko, and V. M. Strilets, "Stend dlya doslidzhennya prystroyiv zminy shvydkosti" ["Stand for research of devices for speed change"], UA Patent 107979, June 24, 2016. [in Ukrainian].

[30] O. R. Strilets, V. O. Malashchenko, and V. M. Strilets, "Stend dlya doslidzhennya prystroyiv zminy shvydkosti" ["Stand for research of devices for speed change"], UA Patent 108298, July 11, 2016. [in Ukrainian].

[31] O. R. Strilets, V. O. Malashchenko, and V. M. Strilets, "Stend dlya doslidzhennya prystroyiv zminy shvydkosti" ["Stand for research of devices for speed change"], UA Patent 108302, July 11, 2016. [in Ukrainian].

[32] R. V. Zinko, I. S. Lozovyy, M. I. Cherevko, and Yu. M. Cherevko, "Metodyka eksperymental $\square$ nykh doslidzhen $\square$ roboty mekhanichnykh system" ["Method of experimental studies of the work of mechanical systems"], Lviv, Ukraine: LISV Publ., 2016. [in Ukrainian]. 